\title{
Using thermoterrace dimensions to calculate the coastal erosion rate
}

Received: 8 August 2003/ Accepted: 29 April 2004/Published online: 18 December 2004

(C) Springer-Verlag 2004

\begin{abstract}
Thermoterraces in syngenetic ice complexes are widespread along the erosion dominated Yakutia Arctic coast. Thermoterraces progressively record quantitative information about their existence, which may be used to determine the mean shore retreat rate during the time they are present. Initial measurements of four thermoterraces on the south coast of the Dmitry Laptev Strait were carried out by the authors in 2002 and shore retreat rates were calculated. Comparison of erosion rates obtained using thermoterrace dimensions and geodetic survey results with those determined using aerial photographs showed that erosion rate values obtained in these two ways are approximately of the same order.
\end{abstract}

\section{Introduction}

Thermoterraces in ice complexes are widespread along the erosion-dominated shores of the Yakutia Arctic coast. The ice complex is a very fine grained, perennially frozen Quaternary sediment with an extremely high ice content in the form of segregated ice and ice wedges. Thermoterraces in ice complexes represent a unique feature of coastal geomorphology, because they store within their physical structure quantitative information about the time of their existence. This information may

\section{F. E. Are}

Petersburg State University of Means of Communications, St.-Petersburg, Russia

\section{N. Grigoriev}

Permafrost Institute SB RAS, Yakutsk, Russia

H.-W. Hubberten · V. Rachold (更)

Alfred Wegener Institute for Polar and Marine Research, Research Unit Potsdam, Telegrafenberg A43,

14473 Potsdam, Germany

E-mail: vrachold(a awi-potsdam.de

Tel.: + 49-331-2882174

Fax: + 49-331-2882137 be used as a basis for calculating mean shore retreat rate $V_{E}$ (coastal erosion rate, m/year) over the lifespan of the thermoterrace. Thermoterraces were first described by Bunge (1895) and Toll (1897). The mechanism of their origin was explained by Are (1968). In subsequent work a technique for calculating $V_{E}$ using thermoterrace dimensions was theoretically established (Are 1985, 1988), but had not been employed until recently due to a lack of the required geodetic measurements. Mcasurement of thermoterrace dimensions was first carried out by the coastal team of the Russian-German expedition "Lena 2002" on the south coast of the Dmitry Laptev Strait $\left(143.6^{\circ} \mathrm{E}\right)$ in August 2002 (Fig. 1). Well-developed single-stage and double-stage thermoterraces in ice complexes are widespread in this area (Fig. 2). A geodetic survey of the shoreline and the edge of the coastal bluffs as well as cross-profile measurements of the four thermoterraces was carried out along a coastal section $3 \mathrm{~km}$ long. Coastal erosion rates at four points were calculated using thermoterrace dimensions obtained from the survey. The coastal erosion rates along a part $(1.600 \mathrm{~m})$ of the coastal section measured were also derived by comparing geodetic survey results with aerial photographs, which allowed both techniques to be verified against one another. Techniques and results of calculations and measurements are presented in this paper.

\section{Methods}

A geodetic survey was carried out on 30 August 2002 using an electronic theodolite with laser distance meter. The measurement resolution was $0.0001^{\circ}$ angular and $0.001 \mathrm{~m}$ linear. Characteristic terrestrial features, which could be identified on aerial photographs, such as sharp turns of small streams, small water bodies, boundaries of different types of vegetation etc., served as natural benchmarks for allocation of the theodolite position by geodetic survey. Point selection for the thermoterrace cross-profile geodetic measurements was made visually. 
Fig. 1 Location of the measurement area $(I)$ and polar stations at Cape Shalaurova (2) and Cape Svyatoy Nos (3)
Fig. 2 Thermoterraces on the south coast of Dmitry Laptev Strait
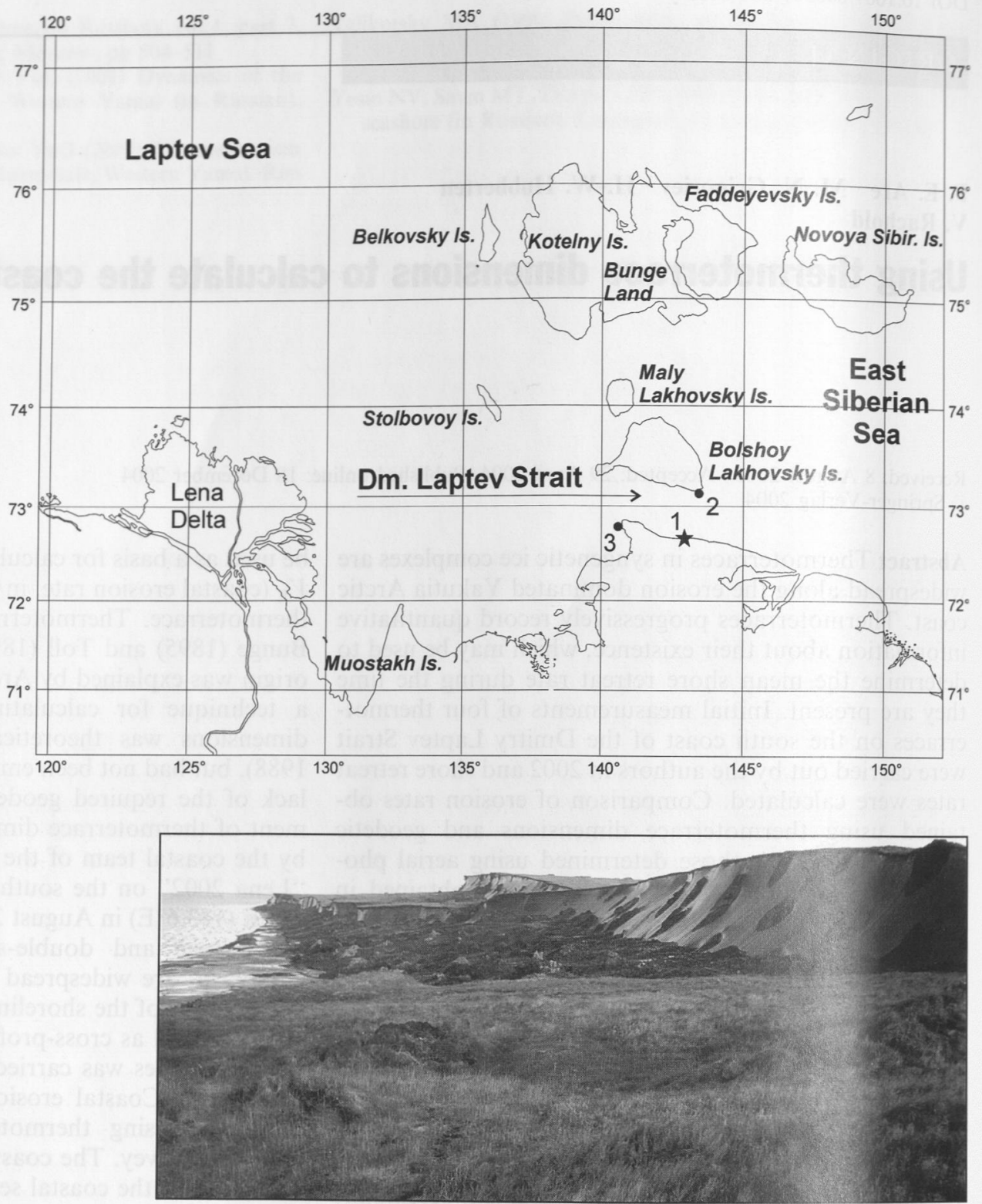

The thermodenudation rate of the ice complex outcrops $\left(V_{\mathrm{T}}\right)$ served as a basis for the calculation of $V_{\mathrm{E}}$. The thermodenudation rate may be calculated using the mean annual sum of the positive mean daily air temperatures ( $\Sigma t$, or thawing-degree days) (Are 1985), and is defined as the amount of surface displacement exhibited by an ice complex in a direction normal to the surface for a specified unit time (meter per year).

Mean values of $\Sigma t$, measured at polar stations (PS), are available from climate handbooks. The stations nearest to the coastal section under investigation are Cape Svyatoy Nos and Cape Shalaurova (Fig. 1). The latter PS is located on B. Lakhovsky Island. However, the $\Sigma t$ values measured on the Laptev Sea Island stations are much less than those measured on the mainland coast. Therefore, we used the sum from Svyatoy Nos PS, which equals to $345^{\circ} \mathrm{C}$ days and is based on 1952-1960 air temperature measurements (Izyumenko 1966).
The calculation of erosion rate for a double-stage thermoterrace profile (Fig. 3) is presented below as an example. The position of the ice complex base above the sea level is an important peculiarity of this thermoterrace. The silt layer underlying the ice complex is characterised by low ice content. The possible total retreat of bluff edges composed of low-ice-content sediments under the impact of thermodenudation is small. The width of thermoterraces in ice complexes ranges from several tens of meters to in excess of $100 \mathrm{~m}$ in some cases. Therefore, the thickness of the silt layer is not a factor in the process of thermoterrace formation, however, the elevation of the ice complex base above sea level must be taken into account when calculating the coastal erosion rate using thermoterrace dimensions.

Unfortunately, in this case the elevation at the base of the ice complex on the thermoterrace profile under consideration was not measured directly. In the coastal 
Fig. 3 The cross-sectional profiles of thermoterraces measured
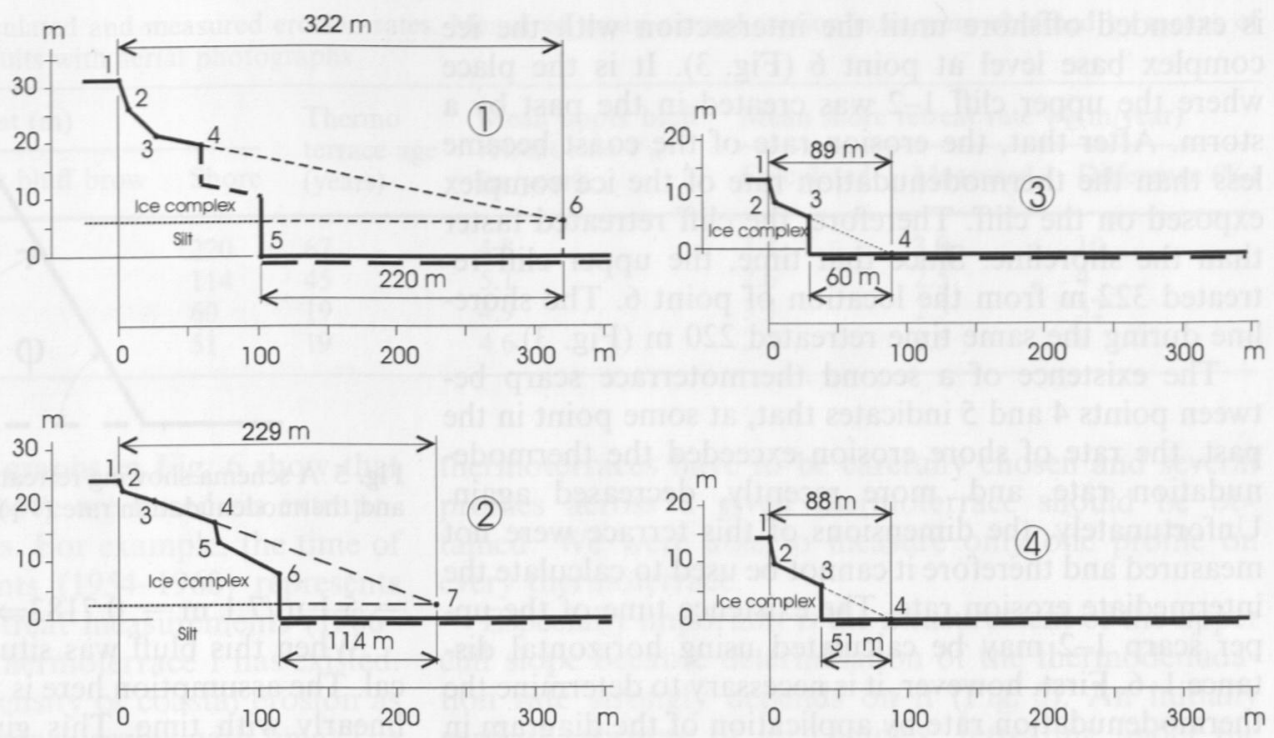

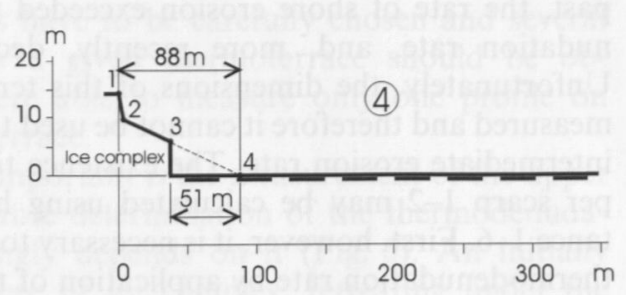

outcrops $540 \mathrm{~m}$ west from this profile it equals $+8 \mathrm{~m}$, and $1,620 \mathrm{~m}$ to the east, $0 \mathrm{~m}$. Linear interpolation of these two points gives an elevation $+6 \mathrm{~m}$ at base of the ice complex on the thermoterrace profile. This value is used for $V_{E}$ calculations. Coordinates of characteristic points of the all four measured thermoterrace profiles, relative to the origin of coordinates shown in Fig. 3, are presented in Table 1 . These coordinates are calculated using geodetic measurements. The surface between points 1 and 2 of the upper scarp of the thermoterrace under consideration (No. 1 in Table 1) represents an exposed ice complex undergoing thermodenudation. The surface between points 3 and 4 is flat, covered by meadow vegetation, and entirely stable. A transition zone from the exposed ice complex to the stable vegetated

Table 1 Coordinates of characteristic points of the four measured thermoterrace profiles relative to the origin of coordinates in Fig. 3

\begin{tabular}{llll}
\hline Terrace & Point & Elevation $(\mathrm{m})$ & Horizontal distance $(\mathrm{m})$ \\
\hline 1 & 1 & 31.4 & 0 \\
& 2 & 26.3 & 7.1 \\
& 3 & 21.5 & 26.5 \\
& 4 & 19.8 & 58.8 \\
2 & 5 & 0 & 101.1 \\
& 1 & 24.5 & 0 \\
& 2 & 22.8 & 2.9 \\
& 3 & 20.9 & 25.5 \\
& 4 & 17.0 & 68.7 \\
& 5 & 13.5 & 71.6 \\
3 & 6 & 7.8 & 114.7 \\
& 7 & 2.5 & 228.6 \\
& 1 & 13.1 & 0 \\
4 & 2 & 9.1 & 4.5 \\
& 3 & 6.5 & 28.8 \\
& 4 & 0 & 89.2 \\
& 1 & 14.5 & 0 \\
& 2 & 9.9 & 3.5 \\
& 3 & 6.0 & 37.2 \\
& 4 & 0 & 88.0 \\
\hline
\end{tabular}

surface is found between points 2 and 3. Blocks of tundra vegetation cover are sliding down the slope in the upper part of this area. In the lower part the vegetation blocks gradually close up and create a continuous cover. The 2-3 surface profile is concave. In the whole 2-3 area the thawing of ice complex and corresponding subsidence of the surface are taking place. These processes will continue until complete thermal and mechanical stabilization has occurred. Consequently, the stable surface 3-4 will advance up slope.

The thermoterrace profile between points 4 and 5 was not measured. Point 5 represents the position of the lower cliff base. This cliff was vertical at the time of measurement with an open wave niche at the base. Point 5 corresponds approximately with the highest sea level.

In August 2002, the coastal erosion rates along a part $(1600 \mathrm{~m})$ of the coastal section measured were also obtained by comparing the present-day position of the shoreline derived from geodetic survey with aerial photographs. The results of geodetic measurements were superposed on aerial photographs taken in 1986 (scale 1:32 000) by computer techniques (ENVI software, version 3.1, BSC Ltd., CO, USA). In that way the total retreat of the shoreline during the 16-year-period was measured and mean annual retreat rates were calculated. These rates vary along the coast from 0.5 to $7.0 \mathrm{~m} /$ year with the average equal to $3.0 \mathrm{~m} /$ year. A reasonable evaluation of possible mistakes by geodetic measurements and distance measurements on the aerial photographs reveals that the rates under discussion may be accurate to about $\pm 0.5 \mathrm{~m} /$ year (Are 1985).

\section{Calculations of the shore retreat rate}

The slope of the stable part of the thermoterrace surface is used for calculating $V_{\mathrm{E}}$. Considering thermoterrace 1 in Fig. 3 it is the slope of section 3-4. The strait line 3-4 
is extended offshore until the intersection with the ice complex base level at point 6 (Fig. 3). It is the place where the upper cliff 1-2 was created in the past by a storm. After that, the erosion rate of the coast became less than the thermodenudation rate of the ice complex exposed on the cliff. Therefore, the cliff retreated faster than the shoreline. Since that time, the upper cliff retreated $322 \mathrm{~m}$ from the location of point 6 . The shoreline during the same time retreated $220 \mathrm{~m}$ (Fig. 3).

The existence of a second thermoterrace scarp between points 4 and 5 indicates that, at some point in the past, the rate of shore erosion exceeded the thermodenudation rate, and, more recently, decreased again. Unfortunately, the dimensions of this terrace were not measured and therefore it cannot be used to calculate the intermediate erosion rate. The existence time of the upper scarp 1-2 may be calculated using horizontal distance 1-6. First, however, it is necessary to determine the thermodenudation rate by application of the diagram in Fig. 4 or by the empirical formula describing this diagram (Are 1985).

$V_{\mathrm{T}}=-3 \times 10^{-6} \cdot(\Sigma t)^{2}+98.10^{-4} \cdot(\Sigma t)+1.22$

The thermodenudation rate calculated by formula (1) using $\Sigma t=345^{\circ} \mathrm{C} \cdot$ days equals $4.25 \mathrm{~m} /$ year.

The retreat rate of the brow of a vertical bluff is equal to $V_{\mathrm{T}}$ but exceeds $V_{\mathrm{T}}$ if the bluff is inclined. The retreat rate for an inclined bluff brow $\left(V_{\mathrm{B}}\right)$ and the thermodenudation rate are related by the formula

$V_{\mathrm{B}}=\frac{V_{\mathrm{T}}}{\sin \varphi}$

where, $\phi$ is the angle of bluff inclination (Fig. 5). The angle $\phi$ for the upper bluff 1-2 of thermoterrace 1, according to the data in Table 1 and Fig. 3, is $\operatorname{tg} \phi$

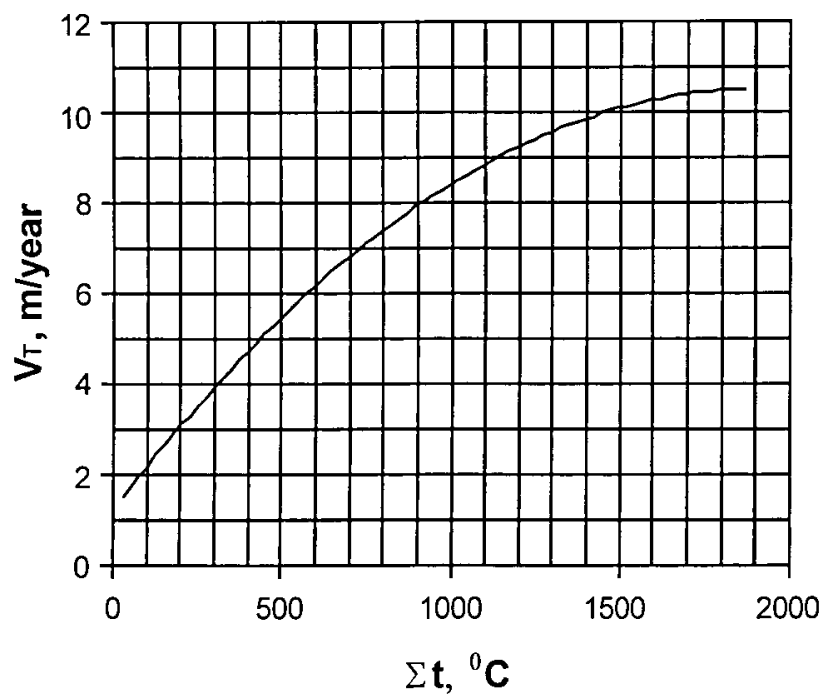

Fig. 4 Thermodenudation rate of the ice bluffs versus the mean annual sum of positive average daily air temperatures (Are 1985)

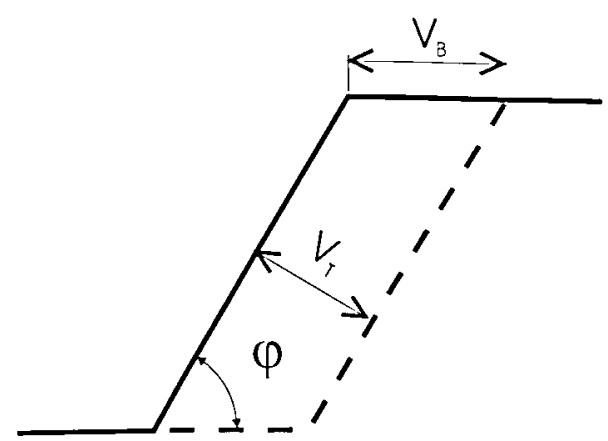

Fig. 5 A schema showing retreat rate of an inclined cliff brow $\left(V_{\mathrm{B}}\right)$ and thermodenudation rate $\left(V_{\mathrm{T}}\right)$

$=5.1 \mathrm{~m} / 7.1 \mathrm{~m}=0.7183 \Rightarrow \phi=35.7^{\circ}$.

When this bluff was situated at point 6 . it was vertical. The assumption here is made that its slope decreased linearly with time. This gives a mean $\phi=(90+35.7) /$ $2=62.85^{\circ}$ and $V_{\mathrm{B}}=4.25 / \mathrm{sin} 62.85^{\circ}=4.78 \mathrm{~m} /$ year. The time of the upper cliff existence is thus EXT $=322 \mathrm{~m}$ : $4.78 \mathrm{~m} /$ year $=67$ years. During this time the lower cliff (point 5 in Fig. 3) retreated by $220 \mathrm{~m}$. The mean rate of shore retreat during the same time was $V_{\mathrm{E}}=220 \mathrm{~m}$ : 67 years $=3.3 \mathrm{~m} /$ year.

The measurement data from the other three terraces (Fig. 3) were processed in the same way. The results of processing are presented in Table 2 . The measured erosion rates obtained by means of comparison of geodetic survey results with aerial photographs are given in the same table. When the rates from the two methods were compared, the rate difference from three sites were within $10 \%$ of measured rates, while at the one site the difference was $32 \%$. Calculated rates were consistently higher than the measured rate.

\section{Discussion}

The measured and calculated coastal retreat rates were relatively similar despite the variability associated with each of the factors used in the calculation. An evaluation of calculation and measurement accuracy is provided. Of particular interest are errors associated with estimating denudation rates from thawing-degree days, measurement of the slope of the thermoterraces, the accuracy of erosion rates measured from aerial photographs, errors of extrapolating over a longer period, and limited correspondence between the points where erosion was measured on aerial photographs and calculated from profiles.

It is pertinent to note that measurements of thermoterraces were carried out as part of the general geodetic survey of the coast and, given the limited time available for fieldwork, these measurements were insufficient for this type of work and results derived from them do not possess high accuracy in general.

The times of thermoterrace existence, air temperature measurements, aerial survey and geodetic measurements 
Table 2 Comparison between calculated and measured erosion rates. Measured mean annual erosion rates were obtained by means of comparison of geodetic survey' results with aerial photographs

\begin{tabular}{|c|c|c|c|c|c|c|c|c|}
\hline \multirow[t]{2}{*}{ Terrace } & \multirow{2}{*}{$\begin{array}{l}\text { Ice complex } \\
\text { base elevation } \\
\text { (m) }\end{array}$} & \multicolumn{2}{|l|}{ Retreat (m) } & \multirow{2}{*}{$\begin{array}{l}\text { Thermo } \\
\text { terrace age } \\
\text { (years) }\end{array}$} & \multirow{2}{*}{$\begin{array}{l}\text { Mean upper bluff } \\
\text { retreat rate } V_{B}^{\prime} \\
\text { (m year) }\end{array}$} & \multicolumn{3}{|c|}{ Mean shore retreat rate $l_{i}(m$ year $)$} \\
\hline & & Lpper bluff brow & Shore & & & Calculated & Measured & Difference $(\%)$ \\
\hline 1 & 6 & 322 & 220 & 67 & 4.8 & 3.3 & 3.0 & 10 \\
\hline 2 & 2.5 & 229 & 114 & 45 & 5.1 & 2.6 & 2.5 & 4 \\
\hline 3 & $<0$ & 89 & 60 & 19 & 4.9 & 3.3 & 2.5 & 32 \\
\hline 4 & $<0$ & 88 & 51 & 19 & 4.6 & 2.7 & 2.5 & 8 \\
\hline
\end{tabular}

are presented in Fig. 6. The graphs in Fig. 6 show that all calculations performed above are based on extrapolation of measurement results. For example, the time of air temperature measurements (1954-1960) represents only $9 \%$, and the coastal retreat measurements (19862002) $24 \%$ of the total time thermoterrace 1 has existed. It is well known that the intensity of coastal erosion as well as air temperature vary considerably with time. The existence of thermoterraces itself reflects the general decrease of coastal erosion rate in the past. Unfortunately, any data on these changes for the area of our investigations are unavailable.

Calculated rates of coastal erosion in Table 2 exceed measured rates by $0.1-0.8 \mathrm{~m} /$ year. Climate warming could cause this difference. Terraces that were measured have existed from 19-67 years. The sum of thawingdegree days used for calculations is based on air temperature measurements carried out during 1954-1960 (over 40 years ago). After that, in 1966-1989, the mean annual air temperature on the Laptev Sea coast and islands stayed stable and even slightly negative trends were observed. But later on, in 1990-1995, the temperature increased by $0.5-1.0^{\circ} \mathrm{C}$ (Skachkov 2001). Therefore, it is tempting to explain calculated and measured shore retreat rate differences as being caused by climate warming. Thorough processing of data on air temperature in Central Yakutia, however, revealed that the mean annual temperature increase was driven by winter warming. Summer temperatures showed almost no trend over this period (Skachkov 2001).

The constant inclination of the thermoterrace surface is a crucial morphological feature for calculation of shore retreat rate. This feature may be clearly observed from a sufficient distance, however the generally flat surface of the terrace is accompanied by a sometimes complicated micro relief. Therefore, to obtain reliable results, the points of geodetic measurements on the thermoterraces have to be carefully chosen and several profiles across a given thermoterrace should be obtained. We were able to measure only one profile on every thermoterrace.

Especially important is the measurement of the upper cliff slope because determination of the thermodenudation rate strongly depends on it (Fig. 5). An initially vertical exposure of ice complex, retreating under the action of thermodenudation, acquires a concave shape with time, with the gradient of exposure decreasing down slope. We could measure only the average gradient of every exposure.

The coastal erosion rate was measured directly only on profile 2 ( $2.5 \mathrm{~m} /$ year in Table 2$)$. In the area of profile 1 , the nearest set of measurements was situated $100 \mathrm{~m}$ to the side ( $3.0 \mathrm{~m} /$ year). An erosion rate of $2.5 \mathrm{~m} /$ year was also measured at a distance of $115 \mathrm{~m}$ from profile 3 and $65 \mathrm{~m}$ from profile 4 . As noted above, the 16-year mean erosion rates measured along a coastal section $1,600 \mathrm{~m}$ long ranged between 1 and $7 \mathrm{~m} /$ year.

Taking into account the variability associated with each of the factors influencing coastal erosion and thermodenudation processes, we believe that amount of data available is insufficient to conduct a useful assessment of accuracy of calculations presented in this paper. Therefore, we prefer to make cautious conclusions.

\section{Conclusions}

The results of field measurements and calculations described in this paper have demonstrated in general that thermoterrace dimensions may be used to calculate retreat rates for coasts composed of ice complexes. Comparison of erosion rates obtained using thermoterrace dimension measurements with rates obtained from geodetic survey results and interpretation of aerial
Fig. 6 Comparison of the thermoterrace existence time (T1-T4) with the time of air temperature measurements (I), and the time between aerial survey and measurements of coastal retreat (2)

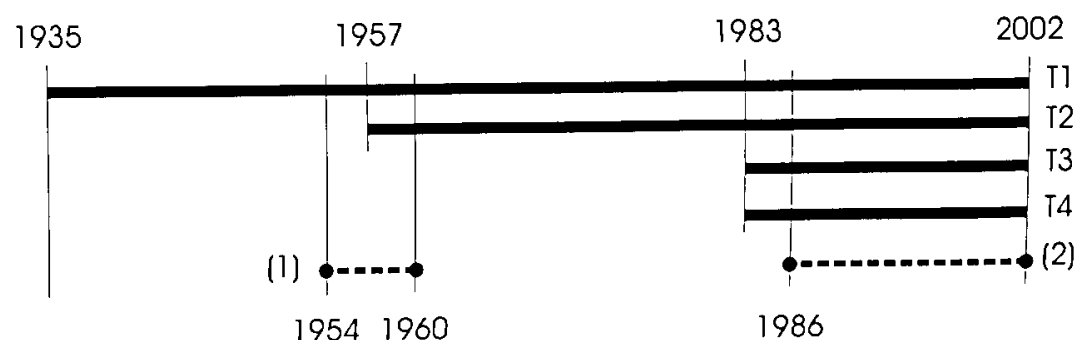

19541960

1986 
photographs showed that the accuracy of erosion rate values obtained in these two ways is approximately of the same order.

Acknowledgements This study was supported by the German Ministry of Education and Research (BMBF) and the Russian Ministry of Research and Technology within the project "Laptev Sea 2000" and by INTAS (project 01-2329). Constructive comments of the reviewers Marina Leibman and Torre Jorgenson, which helped to improve the manuscript, are highly appreciated.

\section{References}

Are FE (1968) Development of the relief on thermoabrasion coasts (in Russian). Trans AS USSR Geogr Ser 1:92-100
Are FE (1985) Principles of shore thermoabrasion forecast (in Russian). Novosibirsk, Nauka, p 172

Are FE (1988) Thermal abrasion of seacoasts. Polar Geogr Geol 12(1-2): 157

Bunge AA (1895) Description of a voyage to the Lena River mouth 1881-1884. Transactions of the Russian polar station in the Lena mouth, Part 1 for 1882 (in Russian). St. Petersburg. Russian Geograph Soc, p 96

Izyumenko SA (ed) (1966) Handbook on USSR climate, Part 24 (in Russian). Leningrad, Hydrometeoizdat, p 398

Skachkov YB (2001) Thermal stability of the upper thicknesses of the Central Yakutia cryolithozone by the modern climate warming (in Russian). Theses abstract. Yakutsk, Permafrost Institute SB RAS, p 22

Toll EV (1897) Fossil glaciers of the New Siberian Islands, their relation to the mammoth corpses and to the Ice Age (in Russian). Notes of the Russian Geograph Soc XXXII(1):139 